\title{
Could Sea Wave-Like Sign Be Used in the Diagnosis of Adult Simple Elbow Dislocations?
}

\author{
Olgun Bingöl' \\ Erman Ceyhan ${ }^{1}$ (D)
}

${ }^{1}$ Orthopaedics and Traumatology Clinic, Ankara City Hospital, Cankaya, Ankara, Turkey

${ }^{2}$ Department of Orthopaedics and Traumatology, Private Ortadogu Hospital, Yenimahalle, Ankara, Turkey

Olgun BINGÖL

Güzelali ÖZDEMIR

Burak KULAKOĞLU

Alper DEVECI

Erman CEYHAN

Correspondence: Olgun Bingöl Orthopaedics and Traumatology Clinic, Ankara City Hospital, Cankaya, Ankara, Turkey

Phone: +9054347241700

E-mail: olgunbingol@gmail.com

\section{ABSTRACT}

Purpose: The elbow is the second most dislocated major joint in adults. This study aimed to evaluate the reliability of the use of 'sea wave-like sign' in adult simple elbow dislocation.

Methods: The study included 12 randomly selected adults with simple elbow dislocation cases. All patients were evaluated with pre-reduction and post-reduction radiographs. The definitive diagnosis of reduction was made with postreduction (T. Evaluations were performed by five orthopedic residents (Group I), five orthopedic specialists with less than 10 years of professional experience (Group II), and five orthopedic specialists with more than 10 years of professional experience (Group III). They were requested to fill out a questionnaire including the reduction and 'sea wave-like sign'.

Results: The specificity of the sea wave-like sign on radiography was $96.6 \%$ and the positive predictive value of this evaluation was $99.1 \%$. There were statistically significant differences between the groups in terms of evaluation of the reduction of the elbow joint. The correct response rates in young specialists were significantly lower than the other two groups $(p<0.05)$. There were no statistically significant differences between the groups in terms of evaluation of the presence of 'sea wave-like sign' $(p=0.266)$.

Conclusion: Sea wave-like sign could be used for adult simple elbow dislocation. The'sea wave-like sign' could reduce the need for CT in a simple elbow dislocation.

Keywords: CT, radiography, sea-wave like sign, simple elbow dislocation

\section{Erişkin basit dirsek çıkıklarının tanısında deniz dalgası benzeri işaret kullanılabilir mi?}

ÖZET

Amaç: Dirsek, yetişkinlerde en çok çıkık olan ikinci ana eklemdir. Bu çalışmanın amacı, erişkin basit dirsek çıkı̆ında'deniz dalgası benzeri işaret' kullanımının güvenilirliğininin değerlendirilmesidir.

Yöntem: Çalışmaya basit dirsek çıkığı olan rastgele seçilmiş 12 yetişkin vaka dahil edildi. Tüm hastaların redüksiyon öncesi ve redüksiyon sonrası radyografileri değerlendirildi. Dirsek redüksiyonunun değerlendirilmesinde kesin tanı yöntemi olarak BT kullanıldı. Değerlendirmeler beş ortopedi asistanı (Grup I), 10 yıldan az mesleki deneyime sahip beş ortopedi uzmanı (Grup II) ve 10 yıldan fazla mesleki deneyime sahip beş ortopedi uzmanı (Grup III) tarafından yapılmıştır. Çalışmadaki 15 hekimden redüksiyonu ve'deniz dalgası benzeri işareti' değerlendirmeleri istendi.

Bulgular: Radyografide deniz dalgası benzeri işaretin özgüllüğü $\% 96,6$ ve bu değerlendirmenin pozitif prediktif değeri $\% 99,1$ olarak tespit edildi. Dirsek eklemindeki redüksiyonun değerlendirilmesi açısından gruplar arasında istatistiksel olarak anlamlı farklılıklar vardı. Genç uzmanlarda doğru yanıt oranları diğer iki gruba göre anlamlı derecede düşük olarak gözlemlendi $(p<0.05)$. Deniz dalgası benzeri işaret varlığının değerlendirilmesi açısından gruplar arasında istatistiksel olarak anlamlı fark yoktu $(p=0,266)$.

Sonuç: Yetişkin basit dirsek çıkı̆̆ı için deniz dalgası benzeri işaret kullanılabilir. Deniz dalgası benzeri işaret, basit bir dirsek çıkığında BT ihtiyacını azaltabilir.

Anahtar Kelimeler: BT, radyografi, deniz dalgası benzeri işaret, basit dirsek çıkı̆ı 
T he elbow is the second most dislocated major joint in adults $(4,8,16)$. They could be simple dislocations that involve only ligamentous and soft tissue injuries or complex dislocations that include bony injuries (4).

Closed reduction is the first step in the management of elbow dislocations. The instability could be manifest with elbow dislocation in some cases. At that time, it is not easy to decide the reduction of the elbow joint with direct radiography. Some criteria were defined previously, but they were often insufficient (10). No consensus has been yet reached on a gold standard method. Therefore, computed tomography (CT) is often used to decide the reduction of the elbow joint.

Previously a new diagnostic radiological criteria, 'sea wave-like sign', was defined to facilitate the diagnosis of incarcerated medial epicondyle fractures in children (12). 'Sea wave-like sign' also could be used for adult simple elbow dislocations (SED) in adults. Hence, the aim of this study was to evaluate the reliability of the use of 'sea wave-like sign' in adult SED.

\section{MATERIALS AND METHODS}

A retrospective review was made of a hospital electronic database to obtain details of patients with adult SED who were treated between January 2015 and April 2018 at Ankara Numune Training and Research Hospital. The study was approved by the Institutional Review Board (E18-2446). Twelve randomly selected cases selected by an evaluator, suitable for radiological and CT examinations, were included in the study.

Adult SED, patients whose pre-reduction and postreduction radiographs could be reached, and patients whose post-reduction computed tomography were included in the present study. Patients under 18 years, patients with previous elbow fracture on the same side, insufficient data, and periprosthetic fractures were excluded.

Previously a new diagnostic radiological criteria, 'sea wave-like sign', was defined to facilitate the diagnosis of incarcerated medial epicondyle fractures in children (12). A parallel double line was seen as a 'sea wave-like sign' on the anterior-posterior elbow radiographs of non-fractured or reduced pediatric patients. The parallelism was seen as disrupted in incarcerated medial epicondyle fractures. The incarcerated fragment distracted in the joint space in the medial compartment of the elbow between the trochlea of the humerus and coracoid of the ulna leads to disruption of this parallel double line. The 'sea wave-like sign' could be seen in adult SED (Figure 1, Figure 2).

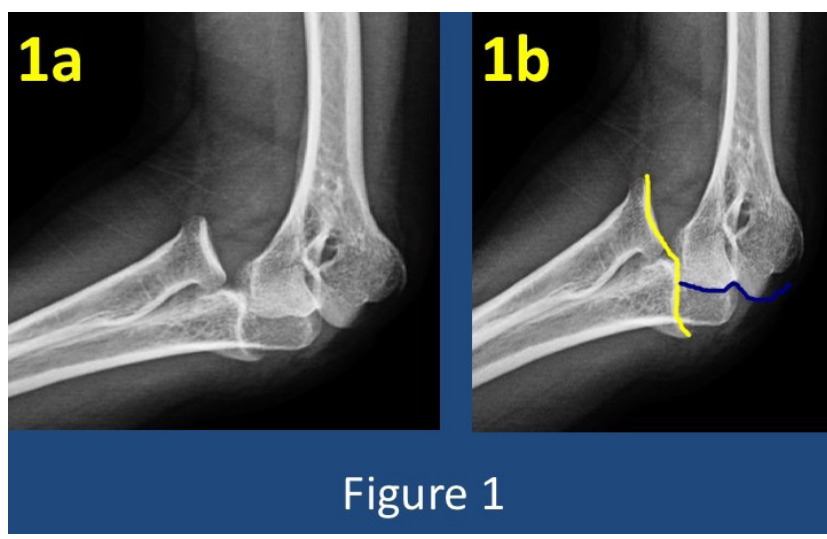

Figure 1.23 years old male with elbow dislocation a- The anteriorposterior elbow radiograph b-The disruption of the 'sea wave-like sign' seen in anterior-posterior elbow radiograph (This means the elbow is dislocated)

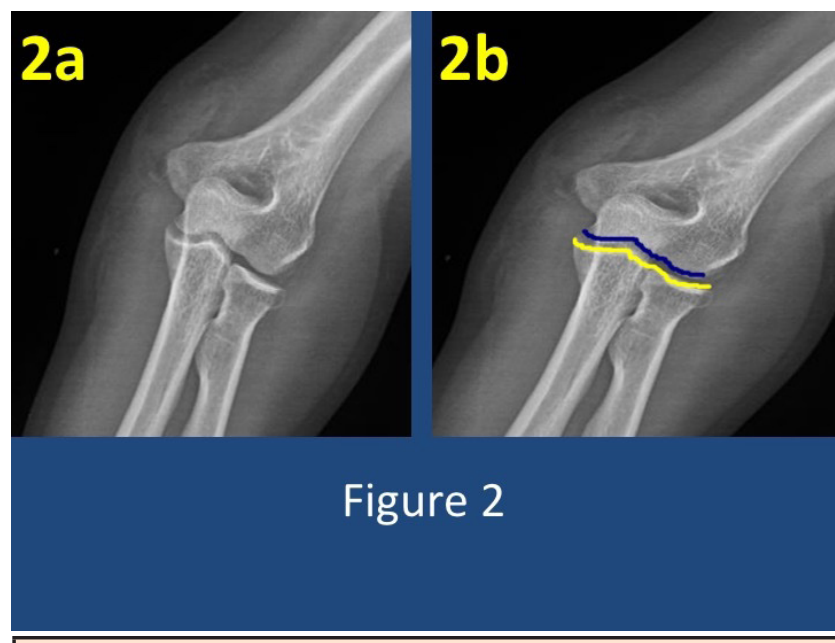

Figure 2. 23 years old male with reduced elbow a The anterior-posterior elbow radiograph b The colored lines indicates that 'sea wave-like sign' seen in anterior-posterior elbow radiograph (This means the elbow is reduced)

All adult patients with SED were evaluated with the same protocol. Closed reduction of the elbow with traction was done at the Emergency Department under sedation with propofol. All patients were evaluated with pre-reduction and post-reduction radiographs. A definitive diagnosis of reduction was made with post-reduction $\mathrm{CT}$.

Evaluations were performed by five Orthopedic residents (Group I), five Orthopedic specialists with less than 10 years of professional experience (Group II), and five 
Orthopedic specialists with more than 10 years of professional experience (Group III). They have evaluated the 12 randomly selected cases with pre-reduction and postreduction anterior-posterior radiographs. They were requested to fill out a questionnaire including the reduction and 'sea wave-like sign'. The reduction of the elbow joint was confirmed by CT in all the randomly selected $12 \mathrm{ca}-$ ses. The observers evaluating the radiographs were blinded to the $C T$ images and the results of the patient. Only the evaluator had access to the full sets of images and results of patients.

\section{Statistical analysis}

Statistical analyses were performed using IBM SPSS Statistics 22.0 (Armonk, NY, USA). Descriptive statistics for the numerical variables were expressed as the mean, standard deviation, and minimum-maximum values. KruskalWallis $\mathrm{H}$ test was used for comparisons of three and more groups, and Wilcoxon sign test was used for pre-post comparisons. The results were evaluated within the $95 \%$ confidence interval and $\mathrm{P}<0.05$ was considered as statistically significant.

\section{RESULTS}

The sensitivity, specificity, positive predictive value, and negative predictive value of the sea wave-like sign on radiography was determined by CT. As a result of 12 evaluations by each 15 observer, 180 evaluations were achieved. The sensitivity of the sea wave-like sign on radiography was $76 \%$ and specificity was $96.6 \%$. Also, the positive predictive value of this evaluation was $99.1 \%$ and the negative predictive value was $44.6 \%$ (Table 1 ).
There were statistically significant differences between the groups in terms of evaluation of the reduction of the elbow joint. The correct response rates in young specialists were significantly lower than the other two groups $(p<0.05)$ (Table 2).

There were no statistically significant differences between the groups in terms of evaluation of the presence of 'sea wave-like sign' $(p=0.266)$ (Table 2 ).

All radiographs were re-evaluated by the same researchers for intra-rater reliability one month after the first evaluation. Intraclass correlation coefficients showed high intra-rater reliability.

\section{DISCUSSION}

In the present study, authors evaluated the reliability of the use of 'sea wave-like sign' in adult SED. The most important finding of the current study was that interobserver and intraobserver agreement of all examiners were high.

There is consensus in the literature about the use of conservative methods in the treatment of adult $\operatorname{SED}(3,6,9)$. However, the outcomes of conservative treatment are not always favorable. Schnetzke et al. emphasized the importance of initial joint stability in SED (14). Therefore, primary soft tissue repair to treat unstable elbow dislocation could be preferred $(7,11,13)$. In the current study, authors made evaluations in 12 randomly selected cases with adult SED, which were treated conservatively.

\section{Table 1: Sensitivity, Specificity, Positive Predictive Value, and Negative Predictive Value of Sea Wave-Like Sign}

\begin{tabular}{|c|c|c|c|c|}
\hline \multicolumn{2}{|c|}{} & \multicolumn{3}{|c|}{ Information Obtained by CT Images } \\
\cline { 2 - 5 } & Reduced & Dislocated & Total \\
\hline \multirow{3}{*}{$\begin{array}{c}\text { Sea Wave-Like Sign on } \\
\text { Radiograph }\end{array}$} & Correct Answer & 114 & 1 & 115 \\
\cline { 2 - 5 } & Wrong Answer & 36 & 29 & 65 \\
\cline { 2 - 5 } & Total & 150 & 30 & 180 \\
\hline * As a result of 12 evaluations by 15 evaluators, 180 evaluations were achieved. &
\end{tabular}

Table 2: The Evaluation of reduction and Sea Wave-Like Sign on Radiograph Between Groups

\begin{tabular}{|c|c|c|c|c|}
\hline & Resident $(\mathbf{n}=\mathbf{5})$ & Young Specialist (n=5) & Senior Specialist (n=5) & $\mathbf{P}$ \\
\hline Evaluation of reduction on radiograph & 11,00 & 9,20 & 11,40 \\
\hline Sea wave-like sign on radiograph & 10,00 & 8,80 & 0,033 \\
\hline *In this study, the evaluation was based on the result of 12 points. & 9,60 \\
\hline
\end{tabular}


There are many studies for the evaluation of elbow joint in direct radiography. The various criteria for evaluating the elbow joint are mentioned in the literature. These criteria are Baumann angle on AP view; hourglass sign, posterior fat bad, anterior humeral line crossing the middle of the capitellum, crossing the line drawn from the coronoid in front of the lateral condyle of the humerus, and humerocapitellar angle on lateral view $(2,5,15)$. Since many of these criteria are aimed to evaluate fractures, the current study aimed to found new criteria for elbow dislocation in AP X-ray.

There are limited studies available in the literature, which evaluated the radiology of the elbow dislocation. Previous studies which have emphasized the importance of lateral radiography were defined some criteria about the reduction of elbow (10). There is not enough definition for evaluation of elbow dislocation on AP X-ray, except the relative articular congruity (1). Nevertheless, it is not easy to decide the reduction of the elbow joint with direct radiography. CT is often used to decide the reduction of the elbow joint. Increased radiation exposure and being not affordable are disadvantages of CT usage. The 'sea wavelike sign' may reduce the need of CT imaging in SED.

This study has several limitations. The radiographic evaluations were not compared with the clinical results. Therefore, further prospective studies are needed. This study was conducted in one single department, and the findings may not necessarily generalizable.

\section{CONCLUSION}

Sea wave-like sign can be used for evaluation in adult SED. The 'sea wave-like sign' may reduce the need for CT imaging in SED. Further prospective studies are needed to compare the results of the radiographic evaluation with the clinical results.

\section{DECLARATIONS}

Funding: There is no funding source.

Conflict of Interest: The authors declare that they have no conflict of interest.

Ethical approval: The study was approved by the Institutional Ethical Committee (E-18-2446).

Availability of data and material: The data and material of the work are deposited by the corresponding author.
Authors' contributions: Design and writing: $\mathrm{OB}$, writing: GO, critically revision: GO, Data Collection: BK, Data analysis: $E C$, revision: $A D$

\section{REFERENCES}

1. Goldfarb CA, Patterson JMM, Sutter M, et al. Elbow radiographic anatomy: measurement techniques and normative data. J shoulder Elb Surg. 2012; 21:1236-46.

2. Grayson DE. The elbow: radiographic imaging pearls and pitfalls. Semin Roentgenol. 2005; 40:223-47.

3. de Haan J, Schep NWL, Tuinebreijer WE, et al. Simple elbow dislocations: a systematic review of the literature. Arch Orthop Trauma Surg. 2010; 130:241-9.

4. Josefsson PO, Gentz CF, Johnell O, et al. Dislocations of the elbow and intraarticular fractures. Clin Orthop Relat Res. 1989; 126-30.

5. Kao H-K, Lee $\mathrm{W}-\mathrm{C}$, Yang $\mathrm{W}-\mathrm{E}$, et al. Clinical significance of anterior humeral line in supracondylar humeral fractures in children. Injury. 2016; 47:2252-7.

6. Kesmezacar $\mathrm{H}$, Sarikaya IA. The results of conservatively treated simple elbow dislocations. Acta Orthop Traumatol Turc. 2010; 44:199-205.

7. Kim BS, Park KH, Song HS, et al. Ligamentous repair of acute lateral collateral ligament rupture of the elbow. J shoulder Elb Surg. 2013; 22:1469-73.

8. Kuhn MA, Ross G. Acute elbow dislocations. Orthop Clin North Am. 2008; 39:155-61.

9. Maripuri SN, Debnath UK, Rao P, et al. Simple elbow dislocation among adults: a comparative study of two different methods of treatment. Injury. 2007; 38:1254-8.

10. McCann F, Canet F, Sandman E, et al. Does radiographic beam angle affect the radiocapitellar ratio measurement of subluxation in the elbow? Clin Orthop Relat Res. 2013; 471:2556-62.

11. Micic I, Kim S-Y, Park I-H, et al. Surgical management of unstable elbow dislocation without intra-articular fracture. Int Orthop. 2009; 33:1141-7.

12. Ozdemir G, Deveci A, Bingol O, et al. A Blocking Barrier During Reduction of the Elbow Dislocation in Children: Incarcerated Medial Epicondyle Fracture. ULUTAS Med J 2018; 4:103-7.

13. Schnetzke $M$, Aytac $S$, Keil $H$, et al. Unstable simple elbow dislocations: medium-term results after non-surgical and surgical treatment. Knee Surg Sports Traumatol Arthrosc. 2017; 25:2271-9.

14. Schnetzke $M$, Aytac $S$, Studier-Fischer $S$, et al. Initial joint stability affects the outcome after conservative treatment of simple elbow dislocations: a retrospective study. J Orthop Surg Res. 2015; 10:128.

15. Shimizu T, Yoshida A, Omokawa S, et al. Importance of anterior humeral line for successful anatomical reduction in the surgical treatment of pediatric supracondylar humeral fractures. J Orthop. 2017; 14:358-62.

16. Stoneback JW, Owens BD, Sykes J, et al. Incidence of elbow dislocations in the United States population. J Bone Joint Surg Am. 2012; 94:240-5. 